\title{
Clinicopathological Characteristics, Treatment, and Prognosis of Rarely Primary Epididymal Adenocarcinoma: A Review and Update
}

\author{
Zi-jun Zou, ${ }^{1}$ Ying-ming Xiao, ${ }^{2}$ Zhi-hong Liu, ${ }^{1}$ Ruo-chen Zhang, ${ }^{3}$ Jia-yu Liang, \\ Yong-quan Tang, ${ }^{1}$ and Yi-ping $\mathrm{Lu}^{1}$ \\ ${ }^{1}$ Institute of Urology, Department of Urology, West China Hospital, Sichuan University, Chengdu, Sichuan 610041, China \\ ${ }^{2}$ Department of Urology, Sichuan Cancer Hospital \& Institute, Chengdu, Sichuan 610041, China \\ ${ }^{3}$ Department of Urology, Fujian Provincial Hospital, Fuzhou, Fujian 350001, China \\ Correspondence should be addressed to Zhi-hong Liu; liuzhihongwch@2980.com
}

Received 27 September 2017; Revised 22 November 2017; Accepted 28 November 2017; Published 20 December 2017

Academic Editor: Ondrej Hes

Copyright (C) $2017 \mathrm{Zi}$-jun Zou et al. This is an open access article distributed under the Creative Commons Attribution License, which permits unrestricted use, distribution, and reproduction in any medium, provided the original work is properly cited.

Primary epididymal adenocarcinoma (PEA) is exceedingly rare. Only 22 cases had been published worldwide by 2008 ; nearly $80 \%$ of these cases were reported before 2007. In order to investigate the current clinical status of PEA, we search for relevant literatures with "epididymis and adenocarcinoma" and "epididymal and adenocarcinoma" as keywords published between January 1997 and November 2017 in PubMed. As a result, 17 cases are identified. We review these cases and summarize new and important perspectives about the clinicopathological characteristics, diagnosis, treatment, and prognosis of PEA in the present review.

\section{Introduction}

Most lesions of the epididymis, including inflammatory and most neoplastic diseases [1], are benign, but rare malignant lesions still should be taken into account in the differential diagnosis. Epididymal cancer is rare, accounting for $0.03 \%$ of all male cancers. $51 \%$ of malignant tumors of the epididymis are primary or metastatic carcinomas and $44 \%$ are sarcomas [2]. Primary epididymal adenocarcinoma (PEA) is one of the epithelial malignancies and even rarer. Ganem and colleagues found only 22 cases were reported worldwide in 2008 [3], but they considered the actual number of PEA patients might be less. Because, in some old cases, PEAs were inadequately described or poorly illustrated, some other tumors such as papillary cystadenoma, adenomatoid tumor and metastatic tumors might be misdiagnosed as PEA [3, 4]. Recently, we searched using "epididymis and adenocarcinoma" and "epididymal and adenocarcinoma" as keywords in PubMed and identified 17 cases about PEA published in the past 20 years between January 1997 and November 2017 [3-16]. Due to its rarity, the natural characteristics of PEA are unclear currently, and diagnosis and treatment have to be based on putative principles. In order to reveal the characteristics and current clinical status of PEA, we summarize the latest 17 cases in terms of clinicopathological characteristics, diagnosis, treatment, and prognosis in the review.

\section{Clinical Features}

PEA patients range in age from 27 to 81 years (mean, 58 years), and nearly $70 \%$ of the patients are older than 50 years in the included cases. Ganem et al. previously reported that about $57 \%$ of PEA patients were older than 50 years [3]. PEA can occur on either side of the epididymis, but no bilateral PEA is reported. History of the disease ranges from 15 days to 40 years before diagnosis, and half of the patients have it more than 6 months. If an epididymal mass enlarges suddenly and rapidly, it may indicate malignancy $[3,5]$. Graham et al. suspected that PEA could arise as a malignant transformation of a benign papillary cystadenoma of the epididymis (PCE) [6]. Relationship between PEA and von Hippel-Lindau disease (VHLD) is not clear with only one 
case revealing such association [7], and thus detection of the VHL gene mutation is not recommended routinely at diagnosis. TP53 gene mutation was detected in a PEA [8].

$80 \%$ of the patients complain of scrotal swelling or palpable mass. About 33\% of the patients suffer from intrascrotal pain. The pain may be associated with the invasive growth pattern of the disease. $38.5 \%$ of PEAs are accompanied by hydrocele.

41.2\% of the PEA patients have localized disease, and others have regional lymph node (LN) and/or distant organ metastasis. Anatomically, there are two lymphatic drainage routes of the epididymis; one is from the epididymis caput and corpus to the preaortic nodes and the other is the epididymis cauda to the external iliac nodes [17]. Retroperitoneal and pelvic LN metastasis are both observed in PEA. Six out of ten metastatic PEAs have retroperitoneal LN metastasis [4, 9-12], and one patient has pelvic LN metastasis [4]. Therefore, retroperitoneal and pelvic LN can be defined as regional LN of PEA. Lung, bone, and abdominal organ are common distant metastatic sites; the metastatic probability is $50 \%, 33.3 \%$, and $33.3 \%$ correspondingly. A positron emission tomography and computed tomography scan (PET/CT) for metastatic evaluation is useful [9], but negative findings can not preclude metastasis [10]. Clinical features are summarized in Table 1.

\section{Pathological Features}

Diagnosis of PEA mainly depends on pathological examination. Macroscopically, the reported maximum diameter of mass ranges from 0.4 to $7 \mathrm{~cm}$ (mean, $3.3 \mathrm{~cm}$ ). It is whitish or tan-yellow and hard. Necrosis, or invasion of surrounding soft tissue, testis, or spermatic cord, is likely to be observed $[3,4,8]$.

Histological features of PEA are variable and mixed (as shown in Table 2). Tubular, papillary, tubulopapillary, cystopapillary, or solid structure can be observed. Cytoplasm of tumor cells is water-clear, amphophilic, or eosinophilic. These mentioned features can also be observed in a benign PCE. However, typical malignant features, such as mitotic figures, nuclear pleomorphism, necrosis, and/or invasive growth pattern, should be observed in a PEA, while absent in a PCE.

Immunohistochemical analysis (IHC) can assist in diagnosing a PEA (as shown in Tables 3 and 4). Markers specific for epithelial tumors, such as cytokeratin and epithelial membrane antigen (EMA), are positive in PEA [9, 11, 13, 14]. PAX2 is important for the development of the Wolffian ducts and thus it is positive in tumors originating from Wolffian ductsassociated organs, containing PEA $[5,18]$. Clear cell papillary cystadenocarcinoma of the epididymis, which has positive CK7, negative RCC marker, and focal immunoreactivity to CD10, can be distinguished from metastatic clear cell renal cell carcinoma (ccRCC) [5]. By contrast, CK7 staining is reportedly negative in mucinous and poorly differentiated adenocarcinoma of the epididymis $[8,9]$. Prostate specific antigen (PSA), placental alkaline phosphatase (PAP), S100, vimentin, alpha fetoprotein (AFP), calretinin, and leukocyte common antigen staining can be performed to exclude
TABLE 1: Clinical features of 17 included cases of primary epididymal adenocarcinoma.

\begin{tabular}{|c|c|}
\hline Variables & Number $\left(\%^{*}\right)$ \\
\hline \multicolumn{2}{|l|}{ Age } \\
\hline Range & $27-81 \mathrm{yr}$ \\
\hline Mean & $58 \mathrm{yr}$ \\
\hline$\leq 50 \mathrm{yr}$ & $5(31.3)$ \\
\hline$>50 \mathrm{yr}$ & $11(68.8)$ \\
\hline Unknown case & 1 \\
\hline \multicolumn{2}{|l|}{ History } \\
\hline Range & $0.5-480 \mathrm{mo}$ \\
\hline$\leq 6 \mathrm{mo}$ & $4(50)$ \\
\hline$>6 \mathrm{mo}, \leq 2 \mathrm{yr}$ & $2(25)$ \\
\hline$>2 \mathrm{yr}$ & $2(25)$ \\
\hline Unknown case & 9 \\
\hline \multicolumn{2}{|l|}{ Clinical presentation } \\
\hline Swelling or mass & $12(80)$ \\
\hline Scrotal pain or discomfort & $5(33.3)$ \\
\hline Incidental finding & $1(6.7)$ \\
\hline Flank and lower abdominal discomfort & $1(6.7)$ \\
\hline Infertility & $1(6.7)$ \\
\hline Unknown case & 2 \\
\hline \multicolumn{2}{|l|}{ Side } \\
\hline Left & $4(36.4)$ \\
\hline Right & $7(63.6)$ \\
\hline Unknown case & 6 \\
\hline \multicolumn{2}{|l|}{ Maximum diameter } \\
\hline Range & $0.4-7 \mathrm{~cm}$ \\
\hline Mean & $3.3 \mathrm{~cm}$ \\
\hline Unknown case & 3 \\
\hline \multicolumn{2}{|l|}{ Hydrocele } \\
\hline Yes & $5(38.5)$ \\
\hline No & $8(61.5)$ \\
\hline Unknown case & 4 \\
\hline \multicolumn{2}{|l|}{ Stage } \\
\hline No metastasis & $7(41.2)$ \\
\hline RLN metastasis & $7(41.2)$ \\
\hline Distant metastasis & $6(35.3)$ \\
\hline Both of RLN and distant metastasis & $3(17.6)$ \\
\hline \multicolumn{2}{|l|}{ Distant metastatic site } \\
\hline Lung & $3(50)$ \\
\hline Bone & $2(33.3)$ \\
\hline Abdominal organ & $2(33.3)$ \\
\hline
\end{tabular}

\#The proportion is calculated in the cases which can offer relevant data. RLN: regional lymph node (including retroperitoneal and pelvic lymph node).

other types of tumors including metastatic prostate cancer, melanoma, sarcoma, testicular tumor, mesothelioma, and lymphoma. However, it should be noted that IHC markers may be expressed in diverse primary cancers, which are not typically associated with the marker expression. IHC results must be interpreted in the context of the overall morphologic features. 


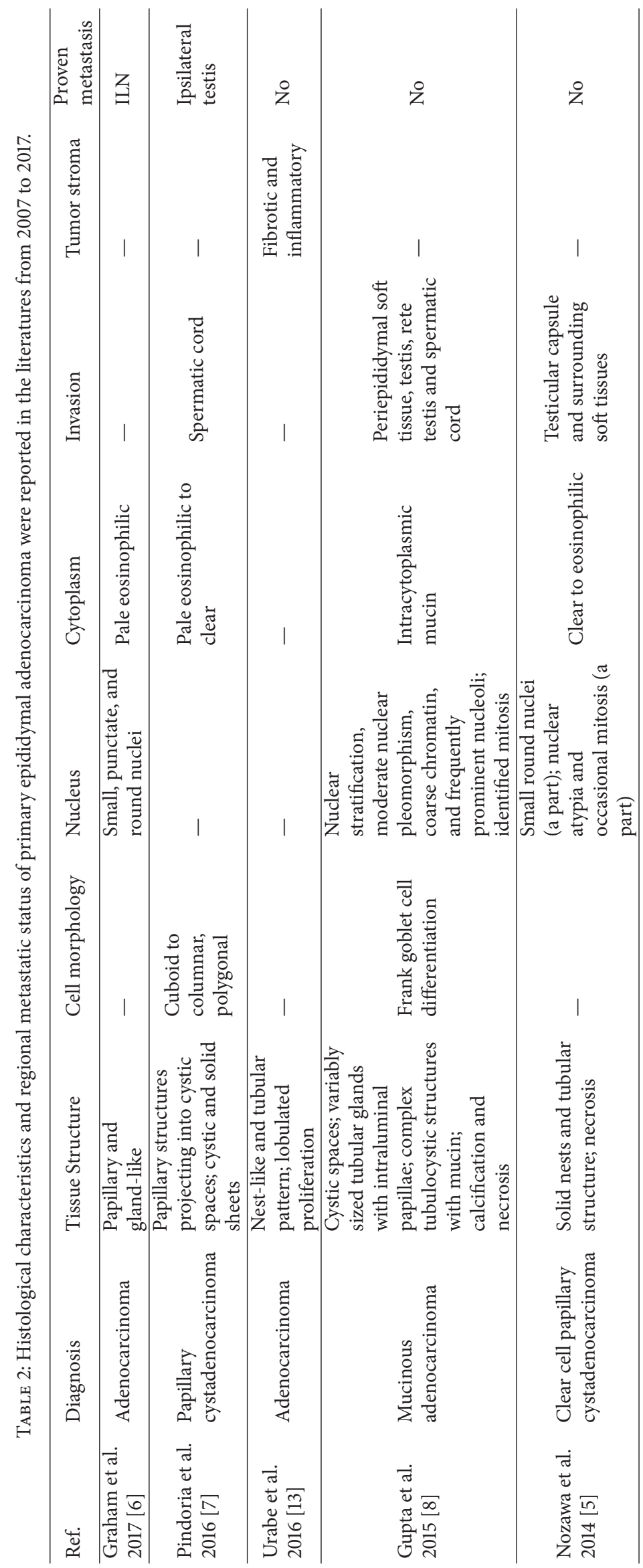




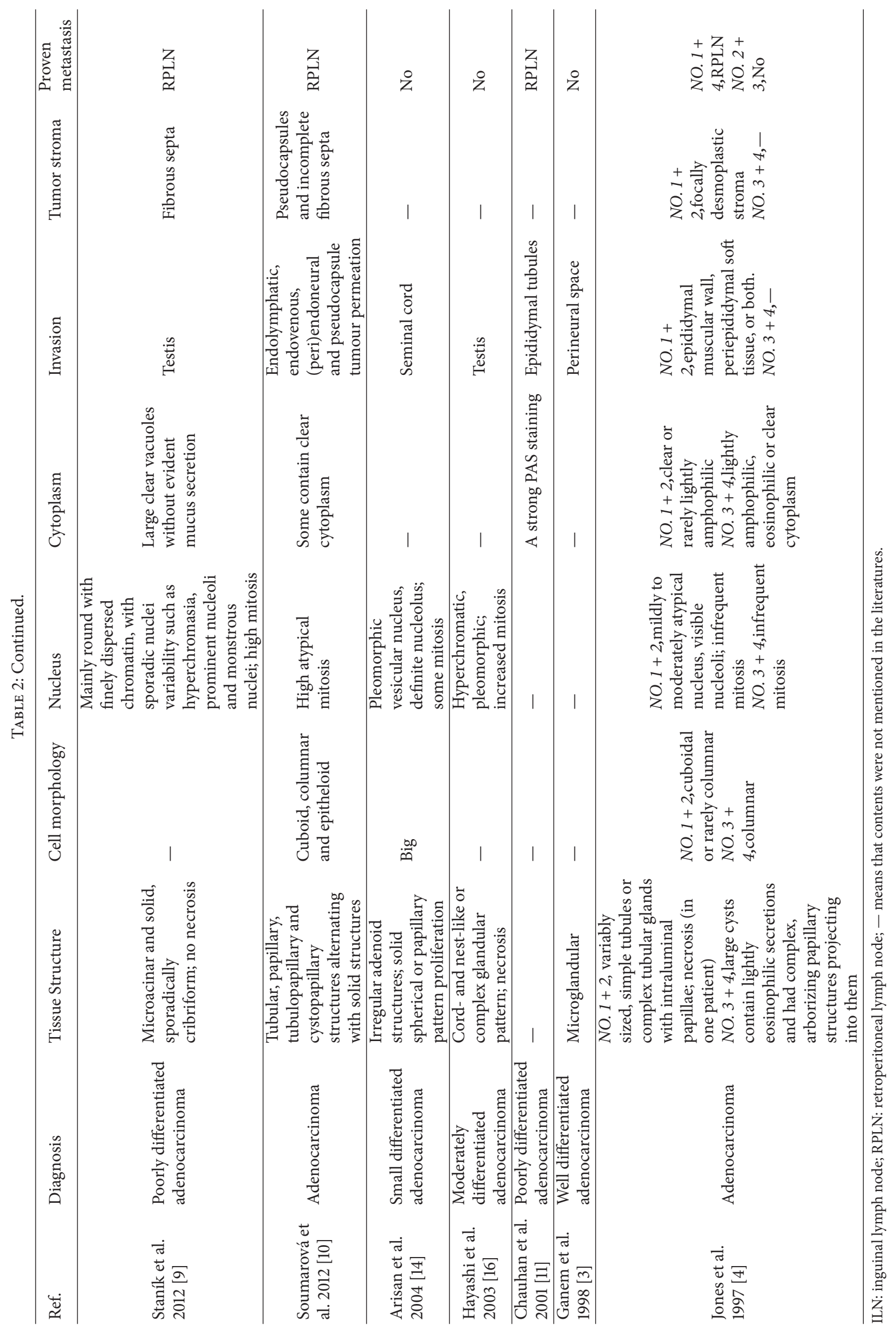


TABLE 3: Markers of immunohistochemical analysis were used for the diagnosis and differentiation of primary epididymal adenocarcinoma in different cases.

\begin{tabular}{|c|c|c|}
\hline Ref. & Type & Immunohistochemical markers \\
\hline $\begin{array}{l}\text { Graham } \\
\text { et al. } \\
2017[6]\end{array}$ & Adenocarcinoma & $\begin{array}{l}\operatorname{CK} 7(+), \operatorname{CD} 10(+), \text { Mesothelin(+), CAIX }(+), \operatorname{PSA}(-), \operatorname{PROSAP}(-), \operatorname{CK} 20(-) \text {, } \\
\text { CDX2(-), WT1(-), SALL4(-), Glypican3(-), CK5(-), Calretinin(-), and } \\
\text { S100(-) }\end{array}$ \\
\hline $\begin{array}{l}\text { Urabe et } \\
\text { al. } \\
2016[13]\end{array}$ & Adenocarcinoma & $\begin{array}{l}\operatorname{EMA}(+), \operatorname{CAM} 5.2(+), \mathrm{C}-\mathrm{KIT}(-), \operatorname{PLAP}(-), \operatorname{AFP}(-), \operatorname{CD} 30(-), \operatorname{HCG}(-), \\
\text { Inhibin(-), Calretinin(-), WT1(-), } \operatorname{HBME1}(-) \text { and } \operatorname{PSA}(-)\end{array}$ \\
\hline $\begin{array}{l}\text { Gupta et } \\
\text { al. } \\
2015[8]\end{array}$ & $\begin{array}{l}\text { Mucinous } \\
\text { adenocarcinoma }\end{array}$ & CK7(-), TTF-1(-), CK20(+), Villin(+), CDX2(-), P53(+) and PAS(+) \\
\hline $\begin{array}{l}\text { Nozawa } \\
\text { et al. } \\
2014[5]\end{array}$ & $\begin{array}{l}\text { Clear cell papillary } \\
\text { cystadenocarcinoma }\end{array}$ & $\begin{array}{l}\mathrm{CK} 7(+), \mathrm{CD} 10(+), \operatorname{PAX} 2(+), \operatorname{Vimentin}(+), \mathrm{CAIX}(+), \text { Vinculin }(+) \text {, } \\
\text { AMACR }(-), \text { RCC marker(-), GST- } \alpha(-) \text { and C-KIT(-) }\end{array}$ \\
\hline $\begin{array}{l}\text { Staník et } \\
\text { al. } \\
2012[9]\end{array}$ & $\begin{array}{l}\text { Poorly differentiated } \\
\text { adenocarcinoma }\end{array}$ & $\begin{array}{l}\operatorname{CK} 7(-), \text { TTF-1(-), CD10(+), CK AE1/AE3(+), EMA }(+), \text { CA19-9(+), } \\
\text { HBME1(+), Inhibin }(-), \text { Calretinin }(-), \operatorname{PLAP}(-), \operatorname{CD} 30(-), \text { Melan-A(-), } \\
\text { CA125(-) and CEA(-) }\end{array}$ \\
\hline $\begin{array}{l}\text { Arisan et } \\
\text { al. } \\
2004[14]\end{array}$ & $\begin{array}{l}\text { Small differentiated } \\
\text { adenocarcinoma }\end{array}$ & $\operatorname{PSA}(-), \operatorname{CEA}(+)$ and $\operatorname{EMA}(+)$ \\
\hline $\begin{array}{l}\text { Hayashi } \\
\text { et al. } \\
2003[16]\end{array}$ & $\begin{array}{l}\text { Moderately } \\
\text { differentiated } \\
\text { adenocarcinoma }\end{array}$ & $\operatorname{AFP}(-), \operatorname{CEA}(-)$ and CA19-9(-) \\
\hline $\begin{array}{l}\text { Chauhan } \\
\text { et al. } \\
2001 \text { [11] }\end{array}$ & $\begin{array}{l}\text { Poorly differentiated } \\
\text { adenocarcinoma }\end{array}$ & $\mathrm{CK}(+), \operatorname{PAS}(+), \operatorname{PAP}(-), \operatorname{LCA}(-), \operatorname{PSA}(-), \operatorname{Vimentin}(-)$ and $\operatorname{S100}(-)$ \\
\hline $\begin{array}{l}\text { Ganem et } \\
\text { al. } \\
1998[3]\end{array}$ & $\begin{array}{l}\text { Well differentiated } \\
\text { adenocarcinoma }\end{array}$ & PSA(-), PAP(-), CEA(+), Vimentin(-) and Leu-M1(-) \\
\hline $\begin{array}{l}\text { Jones et } \\
\text { al. } \\
1997 \text { [4] }\end{array}$ & Adenocarcinoma & $\mathrm{CK}(+), \operatorname{EMA}(+), \operatorname{CEA}(-), \operatorname{AFP}(-)$, Leu-M1(-), B72.3(-) and Ber-EP4(-) \\
\hline
\end{tabular}

Microscopical and IHC features of clear cell papillary cystadenocarcinoma of the epididymis are similar to those of clear cell papillary renal cell carcinoma (ccpRCC) [5]. Though no cases about metastatic ccpRCC in the epididymis were reported to our knowledge, the metastatic disease still should be noted. In order to distinguish the two diseases, specific markers for PEA need to be further explored.

\section{Differential Diagnosis}

Prior to the diagnosis of PEA, metastatic adenocarcinomas should be considered, containing those originating from kidney [7], gastrointestine [19, 20], pancreas [21], bile duct [22], and prostate [23], especially in patients having a history of malignant neoplasms. Pindoria et al. reported that a patient, having a history of multiple renal carcinomas and VHLD, suffered from primary papillary cystadenocarcinoma of the epididymis with testicular metastasis [7]. In this case, metastatic RCC in the testis and epididymis were precluded by histological review, IHC, and imaging detection [7]. Prostate cancer is the most common tumor metastasizing to the epididymis with 27 cases reported [24]. Digital rectal examination, serum PSA detection, transrectal ultrasound, and prostate magnetic resonance imaging are helpful to uncover primary prostate cancer. Similarly, other metastatic adenocarcinomas can be excluded by multidisciplinary evaluation including pathological, endoscopic, and radiological examinations.

The majority of epididymal neoplasms are benign, and adenomatoid tumor is the most common among them. In addition, PCE, leiomyoma, and lipoma can be seen. The differentiation between a PEA and these benign tumors is not difficult by microscopically morphologic and IHC analysis.

\section{Treatment}

Standardized treatment for PEA is lacking. Epididymal malignancies account for approximately $25 \%$ of all epididymal tumors [3]. If an epididymal tumor is strongly suspected, transinguinal exploration is needed. Radical orchiectomy (RO) should be performed, when intraoperative frozen section indicates malignant tumor, both of the epididymis and testis are abnormal, and/or epididymal mass can not be distinguished from the testis. RO promises en bloc tumor excision and is beneficial for subsequent lymphadenectomy because of lymph drainage of the epididymis going along with the spermatic cord into abdomen. Simple excision of PEA may lead to positive surgical margin and recurrence [3], and 
TABLE 4: Summary of immunohistochemical marker expression status in primary epididymal adenocarcinoma.

\begin{tabular}{|c|c|c|}
\hline \multirow{2}{*}{ Marker } & \multicolumn{2}{|c|}{ Primary epididymal adenocarcinoma } \\
\hline & Positive/total cases & Negative/total cases \\
\hline CEA & $2 / 5$ & $3 / 5$ \\
\hline PSA & $0 / 5$ & $5 / 5$ \\
\hline CK7 & $2 / 4$ & $2 / 4$ \\
\hline EMA & $4 / 4$ & $0 / 4$ \\
\hline AFP & $0 / 3$ & $3 / 3$ \\
\hline Calretinin & $0 / 3$ & $3 / 3$ \\
\hline CD10 & $3 / 3$ & $0 / 3$ \\
\hline Vimentin & $1 / 3$ & $2 / 3$ \\
\hline CA19-9 & $1 / 2$ & $1 / 2$ \\
\hline CAIX & $2 / 2$ & $0 / 2$ \\
\hline CD30 & $0 / 2$ & $2 / 2$ \\
\hline CDX2 & $0 / 2$ & $2 / 2$ \\
\hline CK & $2 / 2$ & $0 / 2$ \\
\hline CK20 & $1 / 2$ & $1 / 2$ \\
\hline C-KIT & $0 / 2$ & $2 / 2$ \\
\hline HBME1 & $1 / 2$ & $1 / 2$ \\
\hline Inhibin & $0 / 2$ & $2 / 2$ \\
\hline Leu-M1 & $0 / 2$ & $2 / 2$ \\
\hline PAP & $0 / 2$ & $2 / 2$ \\
\hline PAS & $2 / 2$ & $0 / 2$ \\
\hline PLAP & $0 / 2$ & $2 / 2$ \\
\hline S100 & $0 / 2$ & $2 / 2$ \\
\hline TTF-1 & $0 / 2$ & $2 / 2$ \\
\hline WT1 & $0 / 2$ & $2 / 2$ \\
\hline AMACR & $0 / 1$ & $1 / 1$ \\
\hline B72.3 & $0 / 1$ & $1 / 1$ \\
\hline Ber-EP4 & $0 / 1$ & $1 / 1$ \\
\hline CA125 & $0 / 1$ & $1 / 1$ \\
\hline CAM5.2 & $1 / 1$ & $0 / 1$ \\
\hline CK5 & $0 / 1$ & $1 / 1$ \\
\hline CK AE1/AE3 & $1 / 1$ & $0 / 1$ \\
\hline Glypican & $0 / 1$ & $1 / 1$ \\
\hline GST- $\alpha$ & $0 / 1$ & $1 / 1$ \\
\hline HCG & $0 / 1$ & $1 / 1$ \\
\hline LCA & $0 / 1$ & $1 / 1$ \\
\hline Melan-A & $0 / 1$ & $1 / 1$ \\
\hline Mesothelin & $1 / 1$ & $0 / 1$ \\
\hline P53 & $1 / 1$ & $0 / 1$ \\
\hline PAX2 & $1 / 1$ & $0 / 1$ \\
\hline PROSAP & $0 / 1$ & $1 / 1$ \\
\hline RCC & $0 / 1$ & $1 / 1$ \\
\hline SALL4 & $0 / 1$ & $1 / 1$ \\
\hline Villin & $1 / 1$ & $0 / 1$ \\
\hline Vinculin & $1 / 1$ & $0 / 1$ \\
\hline
\end{tabular}

transscrotal approach carries the risk of lymphatic violation [6].

Anatomically, retroperitoneal lymph node dissection (RPLND) and pelvic lymph node dissection (PLND) may play an important and even curable role in treatment for PEA. Jones and colleagues reported that a PEA patient, with two positive retroperitoneal LNs (a total of 25 nodes were dissected), did not have a relapse for 30 years after early RPLND [4]. Staník et al. recommended performing RPLND not only in PEA with lymphadenopathy but also as prophylactic treatment in clinical N0 disease [9]. Patients with retroperitoneal LN metastasis seem to be more possible to benefit from primary RPLND, even in the case of obviously clinical retroperitoneal LN metastasis at diagnosis $[4,9,10]$, than from secondary surgery in time of retroperitoneal recurrence during the follow-up period $[4,11]$. The role of PLND is still unknown because no relevant cases were reported. In the only case reporting pelvic LN metastasis, external beam radiation was performed instead of PLND [4]. Direct anatomic route for lymphatic drainage from the epididymis to the inguinal LN is absent, and thus inguinal lymph node dissection (ILND) seems not to be necessary as a primary treatment for PEA. ILND was reportedly performed in 3 cases $[4,6,14]$, of which 2 had no evidence of inguinal metastasis postoperatively $[4,14]$. Though inguinal LN metastasis was found in Graham et al's case [6], it was probably secondary to the change of lymphatic drainage route due to previously transscrotal spermatocelectomy.

The evidence of radiotherapy (RT) and chemotherapy for PEA is limited. In one case about a locally relapsed adenocarcinoma of the epididymis, complete remission was achieved 3 months after RT and later the effect lasted 42 months [10]. Platinum-based regimens were used as a first-choice chemotherapy for advanced disease in 3 cases $[10,11,14]$; transient positive effect on disease progression was observed $[9,11]$.

\section{Prognosis}

Prognostic factors of PEA are uncertain. Distant organ metastasis probably indicates poor prognosis. Arisan and colleagues reported a PEA patient, with lateral acetabulum and spleen and liver metastasis, died 6 months after diagnosis [14]. Distant metastasis is also the main cause of death after surgery; patients usually die 6 to 8 months later after distant metastasis $[4,11]$. Chemotherapy may delay the tragic end [8].

Subclinical [10] and clinical retroperitoneal LN metastasis at first diagnosis [9] may have better prognosis than retroperitoneal LN metastasis found during the follow-up period after primary RO $[4,11]$. No retroperitoneal LN metastasis found after RPLND may indicate good prognosis [15].

TP53 gene mutation is likely to be related to poor prognosis of a PEA [8]. The reported treatment and prognosis of PEA are summarized in Table 5.

\section{Conclusion}

PEA is an exceedingly rare malignant tumor. Its diagnosis and treatment are still challenges. Correct diagnosis depends on comprehensively clinical examinations, pathological analysis, and a close follow-up. Early PEA may be cured by radical orchiectomy and appropriate lymph node dissection. Platinum-based chemotherapy and radiotherapy may be 
TABLE 5: Treatment and prognosis of primary epididymal adenocarcinoma reported in the literatures from 2007 to 2017.

\begin{tabular}{|c|c|c|c|c|c|}
\hline Ref. & Primary treatment & IFP & Interval time ${ }^{*}$ & $\begin{array}{l}\text { Secondary } \\
\text { treatment }\end{array}$ & $\begin{array}{l}\text { Follow-up time } \\
\text { and prognosis }\end{array}$ \\
\hline $\begin{array}{l}\text { Graham et al. } \\
2017 \text { [6] }\end{array}$ & $\begin{array}{l}\text { Epididymectomy, } \\
\text { RO, scrotectomy, } \\
\text { resection of the } \\
\text { inguinal mass and } \\
\text { ILND }\end{array}$ & No use & - & - & $\begin{array}{l}12 \mathrm{mo} \text {; right ILN } \\
\text { and suspected } \\
\text { pulmonary } \\
\text { metastasis }\end{array}$ \\
\hline $\begin{array}{l}\text { Pindoria et al. } \\
2016 \text { [7] }\end{array}$ & A biopsy & No use & $\begin{array}{l}\text { After having a } \\
\text { child by IVF } \\
\text { treatment }\end{array}$ & $\begin{array}{l}\mathrm{RO} \text { and } \\
\text { onco-micro TeSE }\end{array}$ & - \\
\hline $\begin{array}{l}\text { Urabe et al. } \\
2016[13]\end{array}$ & $\mathrm{RO}$ & No use & - & - & $\begin{array}{l}10 \text { mo; no evidence } \\
\text { of metastasis and } \\
\text { recurrence }\end{array}$ \\
\hline $\begin{array}{l}\text { Gupta et al. } \\
2015[8]\end{array}$ & $\mathrm{RO}$ & No use & $2 \mathrm{yr}$ & $\begin{array}{l}\text { Chemotherapy } \\
\text { (capecitabine) }\end{array}$ & $\begin{array}{l}30 \text { mo; bilateral } \\
\text { pulmonary } \\
\text { metastasis was } \\
\text { found } 2 \mathrm{yr} \text { after } \\
\text { surgery and the } \\
\text { lesions were stable } \\
6 \text { mo later }\end{array}$ \\
\hline $\begin{array}{l}\text { Nozawa et al. } \\
2014[5] \\
\end{array}$ & $\mathrm{RO}$ & - & - & - & - \\
\hline $\begin{array}{l}\text { Staník et al. } \\
2012[9]\end{array}$ & $\mathrm{RO}$ & No use & $4 \mathrm{mo}$ & $\begin{array}{l}\text { RPLND and } \\
\text { chemotherapy } \\
\text { (paclitaxel and } \\
\text { carboplatin) }\end{array}$ & $\begin{array}{l}20 \text { mo; no evidence } \\
\text { of metastasis and } \\
\text { recurrence }\end{array}$ \\
\hline $\begin{array}{l}\text { Soumarová et } \\
\text { al. } 2012 \text { [10] }\end{array}$ & $\begin{array}{l}\text { Orchiectomy, } \\
\text { RPLND }\end{array}$ & - & $6 \mathrm{mo}$ & Palliative RT & $\begin{array}{l}48 \text { mo; scrotal } \\
\text { recurrence was } \\
\text { found } 6 \text { mo after } \\
\text { surgery and the } \\
\text { lesion was } \\
\text { complete remission } \\
42 \text { mo after RT }\end{array}$ \\
\hline $\begin{array}{l}\text { Yang et al. } \\
2010[15]\end{array}$ & RO, RPLND & Yes & - & - & $\begin{array}{l}\text { At least } 10 \text { mo; no } \\
\text { evidence of } \\
\text { metastasis and } \\
\text { recurrence }\end{array}$ \\
\hline $\begin{array}{l}\text { Arisan et al. } \\
2004[14]\end{array}$ & $\begin{array}{l}\text { RO, unilateral } \\
\text { ILND and } \\
\text { chemotherapy } \\
\text { (cisplatin and } \\
\text { etoposide) }\end{array}$ & No use & - & - & $\begin{array}{l}\text { Patient died of } \\
\text { right lateral } \\
\text { acetabulum and } \\
\text { spleen and liver } \\
\text { metastasis after } \\
6 \text { mo }\end{array}$ \\
\hline $\begin{array}{l}\text { Hayashi et al. } \\
2003[16]\end{array}$ & $\mathrm{RO}$ & No use & - & - & $\begin{array}{l}17 \text { mo; no evidence } \\
\text { of metastasis and } \\
\text { recurrence. }\end{array}$ \\
\hline $\begin{array}{l}\text { Chauhan et } \\
\text { al. } 2001[11]\end{array}$ & $\mathrm{RO}$ & Yes & $1 \mathrm{yr}$ & $\begin{array}{l}\text { RPLND and } \\
\text { radiochemother- } \\
\text { apy }(2 \mathrm{nd}) ; \\
\text { palliative } \\
\text { chemotherapy } \\
\text { (3rd) }\end{array}$ & $\begin{array}{l}\text { Patient died after } \\
30 \text { mo. RLN } \\
\text { metastasis } \\
\text { occurred } 1 \text { yr after } \\
\text { initial surgery. } \\
\text { Multiple bone } \\
\text { metastasis } \\
\text { occurred } 1 \text { yr after } \\
\text { secondary } \\
\text { treatment }\end{array}$ \\
\hline $\begin{array}{l}\text { Ganem et al. } \\
1998 \text { [3] }\end{array}$ & $\begin{array}{l}\text { Transscrotal } \\
\text { epididymectomy }\end{array}$ & No use & $1 \mathrm{mo}$ & $\begin{array}{l}\text { Radical } \\
\text { orchiectomy and } \\
\text { hemiscrotectomy }\end{array}$ & $\begin{array}{l}18 \text { mo; no evidence } \\
\text { of metastasis and } \\
\text { recurrence. }\end{array}$ \\
\hline
\end{tabular}


TABLE 5: Continued.

\begin{tabular}{|c|c|c|c|c|c|}
\hline Ref. & Primary treatment & IFP & Interval time ${ }^{*}$ & $\begin{array}{l}\text { Secondary } \\
\text { treatment }\end{array}$ & $\begin{array}{l}\text { Follow-up time } \\
\text { and prognosis }\end{array}$ \\
\hline $\begin{array}{l}\text { Jones et al. } \\
1997[4]\end{array}$ & $\begin{array}{l}\text { (1) RO } \\
\text { (2) RO and RT } \\
\text { (3) RO } \\
\text { (4) RO, RPLND } \\
\text { and ILND }\end{array}$ & $\begin{array}{l}\text { (1) No use } \\
\text { (2) No use } \\
\text { (3) No use } \\
\text { (4) No use }\end{array}$ & $\begin{array}{l}\text { (1) } 1 \mathrm{yr} \\
\text { (2) }- \\
\text { (3) - } \\
\text { (4) }-\end{array}$ & $\begin{array}{l}\text { (1) RPLND } \\
\text { (2) - } \\
\text { (3) - } \\
\text { (4) - }\end{array}$ & $\begin{array}{l}\text { (1) Patient died } \\
\text { after } 20 \text { mo. RLN } \\
\text { metastasis } \\
\text { occurred } 1 \text { yr after } \\
\text { initial surgery. } \\
\text { Bilateral lung } \\
\text { metastasis } \\
\text { occurred } 8 \text { mo } \\
\text { later. } \\
\text { (2) Patient died of } \\
\text { extensive } \\
\text { abdominal and } \\
\text { PLN metastases } \\
\text { after } 6 \text { mo. } \\
\text { (3)- } \\
\text { (4) } 30 \text { yr; no } \\
\text { evidence of } \\
\text { metastasis and } \\
\text { recurrence }\end{array}$ \\
\hline
\end{tabular}

IFP: intraoperative frozen pathology; ILN: inguinal lymph node; ILND: inguinal lymph node dissection; IVF: in vitro fertilization; onco-micro TeSE: microsurgical testicular sperm extraction in cancer patients; PLN: pelvic lymph node; RPLN: retroperitoneal lymph node; RPLND: retroperitoneal lymph node dissection; RO: radical orchiectomy; RT: radiotherapy. ${ }^{*}$ interval time indicates the time between primary and secondary treatment.

transiently effective on late and relapsed PEA. Distant organ metastasis probably indicates poor prognosis.

\section{Conflicts of Interest}

All authors in the study declare no conflicts of interest.

\section{Authors' Contributions}

Zi-jun Zou, Zhi-hong Liu, and Ying-ming Xiao wrote and edited the manuscript. Ruo-chen Zhang and Jia-yu Liang collected these articles. Yong-quan Tang and Yi-ping Lu prepared tables. All authors reviewed the manuscript. Zi-jun Zou, Ying-ming Xiao, and Zhi-hong Liu contributed to this work equally.

\section{Acknowledgments}

The authors thank Shi-qiang Zhang, from the Department of Urology of the Seventh Affiliated Hospital of Sun Yat-sen University (Shenzhen, China), for editing the English text of a draft of this manuscript. This work was supported by the Science and Technology Foundation of the Sichuan Province (2017SZ0123 to Zhi-hong Liu) and 1.3.5 Project for Disciplines of Excellence, West China Hospital, Sichuan University.

\section{References}

[1] C. C. Yu, J. K. Huang, H. Chiang, M. T. Chen, and L. S. Chang, "Papillary Cystadenocarcinoma of the Epididymis: A Case Report and Review of the Literature," The Journal of Urology, vol. 147, no. 1, pp. 162-165, 1992.
[2] C. H. Yeung, K. Wang, and T. G. Cooper, "Why are epididymal tumours so rare?" Asian Journal of Andrology, vol. 14, no. 3, pp. 465-475, 2012.

[3] J. P. Ganem, F. M. Jhaveri, and M. C. Marroum, "Primary adenocarcinoma of the epididymis: Case report and review of the literature," Urology, vol. 52, no. 5, pp. 904-908, 1998.

[4] M. A. Jones, R. H. Young, and R. E. Scully, "Adenocarcinoma of the epididymis: A report of four cases and review of the literature," The American Journal of Surgical Pathology, vol. 21, no. 12, pp. 1474-1480, 1997.

[5] T. Nozawa, R. Konda, T. Ohsawa et al., "Clear cell papillary cystadenocarcinoma of the epididymis: A case report and immunohistochemistry of markers for renal cell carcinoma," Histology and Histopathology, vol. 28, no. 3, pp. 321-326, 2014.

[6] L. Graham, L. D. True, and M. T. Schweizer, "Metastatic Adenocarcinoma of the Epididymis: A Case Report and Brief Literature Review," Clinical Genitourinary Cancer, 2017.

[7] N. Pindoria, Y. Miki, A. Tay et al., "Epididymal papillary cystadenocarcinoma metastasising to the testis in a patient with infertility managed with Onco-microTeSE," Journal of Surgical Case Reports, vol. 2016, no. 11, pp. 1-3, 2016.

[8] S. Gupta, B. Yan, P. C. Leow, S. Y. Chin, R. Soong, and F. Petersson, "Primary mucinous adenocarcinoma of the epididymis: Report of a rare case with molecular genetic characterization including mutation analysis of the TP53 gene," Applied Immunohistochemistry \& Molecular Morphology, vol. 23, no. 4, pp. 308312, 2015.

[9] M. Staník, J. Doležel, D. Macík, A. Krpenský, and R. Lakomý, "Primary adenocarcinoma of the epididymis: The therapeutic role of retroperitoneal lymphadenectomy," International Urology and Nephrology, vol. 44, no. 4, pp. 1049-1053, 2012.

[10] R. Soumarová, V. Maňásek, H. Perková, and I. Ferák, "Radiotherapy in the treatment of epididymal adenocarcinoma - Case report," Onkologie, vol. 35, no. 1-2, pp. 43-45, 2012. 
[11] R. D. Chauhan, J. R. Gingrich, M. Eltorky, and M. S. Steiner, "The natural progression of adenocarcinoma of the epididymis," The Journal of Urology, vol. 166, no. 2, pp. 608-610, 2001.

[12] Z. P. Joos, T. R. Pritchett, C. R. Porter, C. Isacson, V. Picozzi, and J. M. Corman, "Adenocarcinoma of the testicular adnexa presenting with metastatic disease.," The Canadian journal of urology., vol. 13, no. 1, pp. 2990-2992, 2006.

[13] F. Urabe, T. Kimura, T. Yanagisawa et al., "A case of adenocarcinoma of the epididymis with hydrocele," Nihon Hinyokika Gakkai Zasshi, vol. 107, no. 3, pp. 193-197, 2016.

[14] S. Arisan, O. N. Akbulut, O. O. Cakir, and E. Ergenekon, "Primary adenocarcinoma of the epididymis: Case report," International Urology and Nephrology, vol. 36, no. 1, pp. 77-80, 2004.

[15] WZ. Yang, ZY. Cui, W. Zhang, HY. Zhou, QS. Wang, and YQ. Zhang, "Diagnosis and treatment of primary epididymal tumor: a report of 35 cases," Cases Zhonghua Nan Ke Xue, vol. 16, no. 6, pp. 527-230, 2010.

[16] I. Hayashi, N. Satoh, N. Kanemitsu et al., "A case of primary adenocarcinoma of the epididymis," Acta Urologica Japonica, vol. 49, no. 6, pp. 341-343, 2003.

[17] L. R. Kavoussi, A. W. Partin, A. C. Novick, and C. A. Peters, Campbell-Walsh Urology, Ed. Elsevier Saunders, Philadelphia, Penn, USA, 10th edition, 2012.

[18] R. Cox, R. Vang, and J. I. Epstein, "Papillary cystadenoma of the epididymis and broad ligament: Morphologic and immunohistochemical overlap with clear cell papillary renal cell carcinoma," The American Journal of Surgical Pathology, vol. 38, no. 5, pp. 713-718, 2014.

[19] J. M. Janeiro Pais, L. Busto Castañón, A. Barbagelata López et al., "Metastasis of colon adenocarcinoma to the epididymis and spermatic cord," Archivos Españoles de Urología, vol. 59, no. 7, pp. 746-748, 2006.

[20] A. Ahmad, N. P. Libbey, P. Somasundar, and S. C. Katz, "Gastrointestinal stromal tumour metastatic to the epididymis," $B M J$ Case Reports, vol. 2015, Article ID 211555, 2015.

[21] X. Zhu, Z. Meng, Z. Chen et al., "Metastatic adenocarcinoma of the epididymis from pancreatic cancer successfully treated by chemotherapy and high-intensity focused ultrasound therapy: A case report and review of the literature," Pancreas, vol. 40, no. 7, pp. 1160-1162, 2011.

[22] V.S. Bennett and D. M. Bailey, "Cholangiocarcinoma presenting as a solitary epididymal metastasis: A case report and review of the literature," Diagnostic Pathology, vol. 2, no. 1, article no. 33, 2007.

[23] C. C. Rizk, J. Scholes, S. K.-Z. Chen, J. Ward, and N. A. Romas, "Epididymal metastasis from prostatic adenocarcinoma mimicking adenomatoid tumor," Urology, vol. 36, no. 6, pp. 526-530, 1990.

[24] S. Santos-Lopes, J. Lobo, R. Henrique, and J. Oliveira, "Epididymal metastasis from prostate adenocarcinoma: An unusual and challenging diagnosis suspected in gallium- 68 prostate-specific membrane antigen-positron emission tomography/computed tomography and histologically confirmed," Urology Annals, vol. 9, no. 1, pp. 89-91, 2017. 


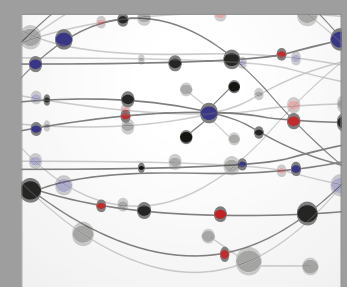

The Scientific World Journal
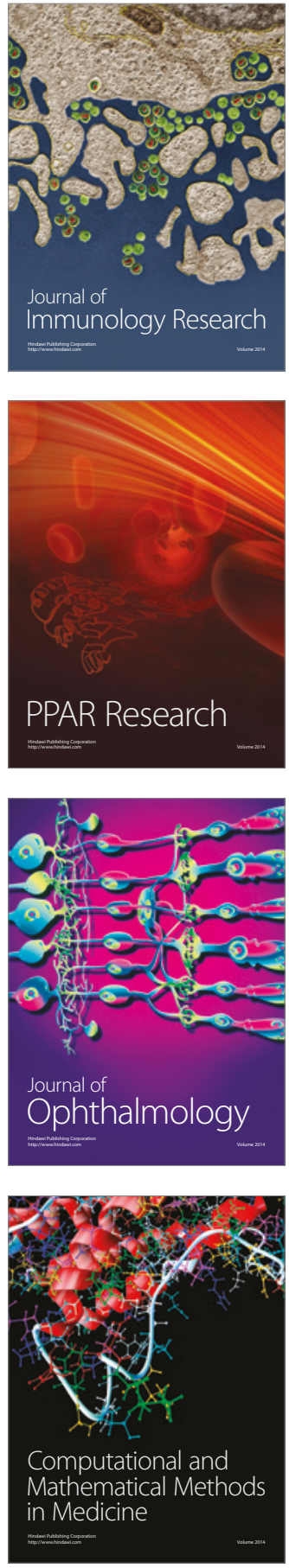

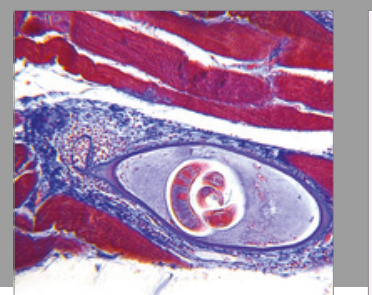

Gastroenterology Research and Practice
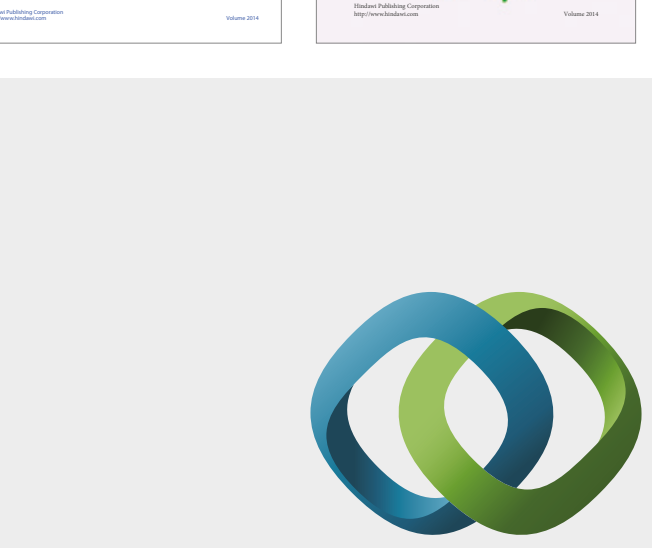

\section{Hindawi}

Submit your manuscripts at

https://www.hindawi.com
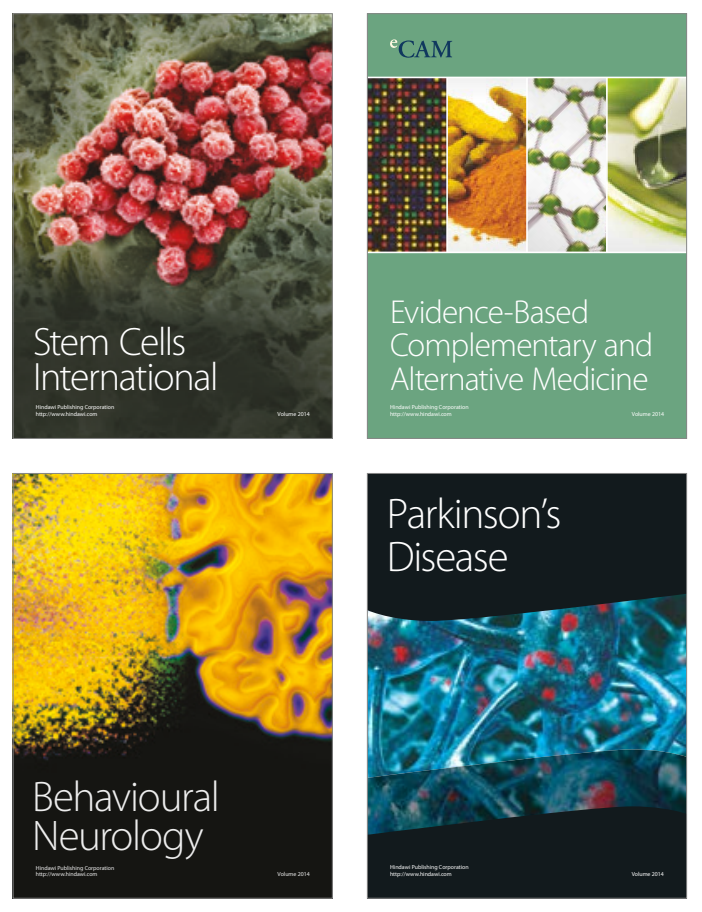
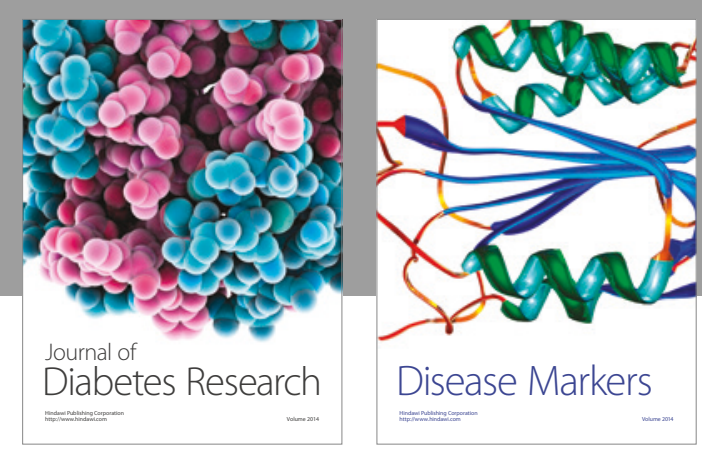

Disease Markers
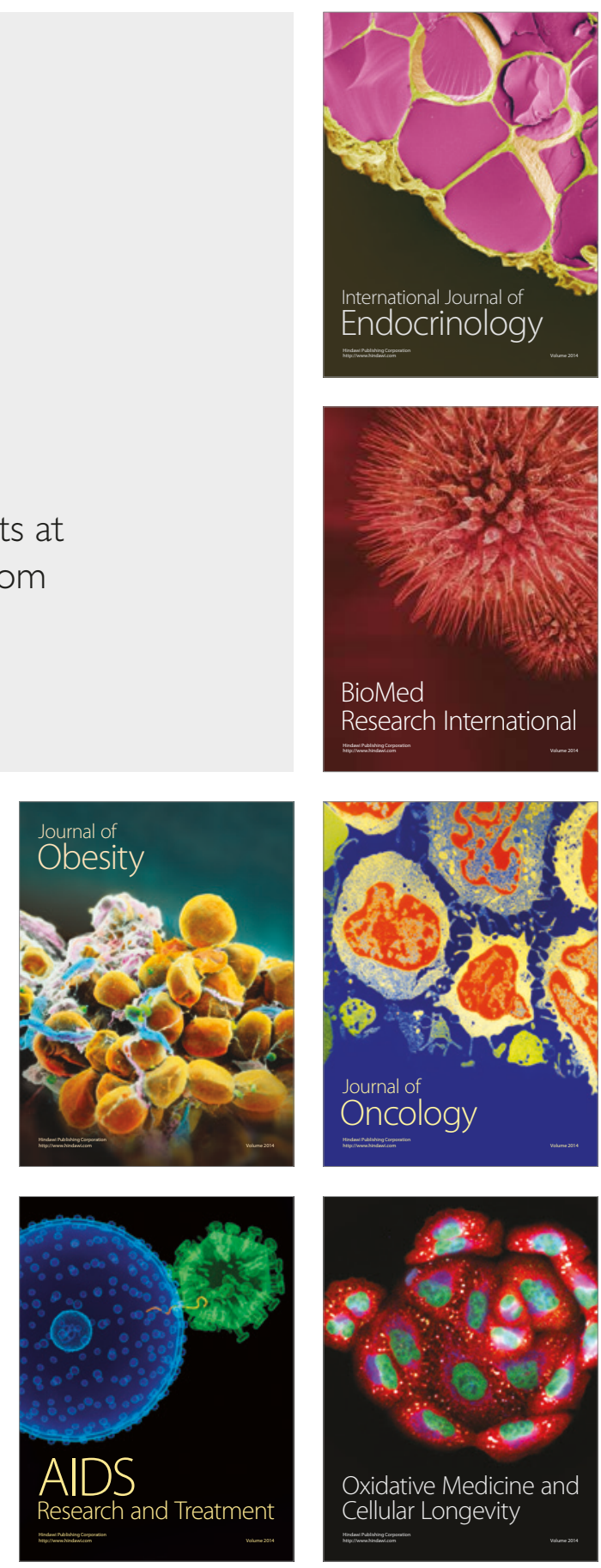